\title{
COMPARATIVE STUDIES ON ADRENAL CORTICAL FUNCTION AND CORTISOL METABOLISM IN HEALTHY ADULTS AND IN PATIENTS WITH SHOCK DUE TO INFECTION
}

\author{
By JAMES C. MELBY AND WESLEY W. SPINK \\ (From the University of Minnesota Medical School, Minneapolis, Minn.)
}

(Submitted for publication April 28, 1958; accepted August 28, 1958)

Secretory failure of the adrenal glands has continued to be implicated as a factor in the pathogenesis of peripheral circulatory collapse due to infection since the original reports of Waterhouse (1) and of Friderichsen (2). This association of adrenal function and circulatory failure has been cited in recent reviews (3-5). However, a deficit of adrenal secretory products or their urinary metabolites in peripheral collapse due to infection has not been reported. Investigations in our laboratory have shown that shock produced in dogs by endotoxins of gram-negative bacteria was accompanied by an elevation of the concentration of cortisol in the plasma, and the output of cortisol in adrenal venous blood rose abruptly immediately after the injection of endotoxin (6).

This report is concerned with the assessment of adrenal cortical function in human patients having peripheral circulatory failure due to severe infections. Studies with a 21-hemisuccinate ester of cortisol, which is rapidly hydrolyzed to free cortisol in vivo, were undertaken in order to delineate the metabolism of cortisol, the principal adrenal secretory product in man (7).

\section{METHODS}

The subjects in this study included 9 healthy adults and 22 patients with severe infections complicated by circulatory collapse. Fifteen of these patients had demonstrable bacteremia at the time the studies were carried out. All of the patients were hypotensive with systolic blood pressures under $90 \mathrm{~mm}$. of $\mathrm{Hg}$. A summary of the clinical data on these patients is recorded in Table I.

Blood samples for the determination of cortisol concentrations in the plasma were analyzed by a modification of the method of Silber and Porter (8) as described by Peterson, Karrer and Guerra (9). This method is specific for steroids with the 17,21-dihydroxy-20-keto configuration including cortisol, cortisone, Compound $\mathrm{S}$ and their dihydro- and tetrahydro- derivatives. Of these, only cortisol exists in the plasma in significant concentrations; therefore, the method may be regarded as highly specific for cortisol.
Adrenal stimulation was carried out in eight normal subjects and in six patients with shock due to infection by an intravenous infusion of 25 U.S.P. units of corticotropin (Upjohn, Sterile Corticotropin Injection) dissolved in $500 \mathrm{ml}$. of 5 per cent dextrose in water, which was given over a period of four hours. Specimens of 15 $\mathrm{ml}$. of heparinized blood were secured initially and at the conclusion of the infusion of corticotropin. The erythrocytes were separated from the plasma within 30 minutes. The samples were frozen and plasma cortisol levels were determined within 72 hours.

In order to determine the rate of disappearance of exogenous cortisol, an intravenous injection of $100 \mathrm{mg}$. of cortisol sodium succinate dissolved in $2 \mathrm{ml}$. of distilled water (Upjohn, Hydrocortisone Sodium Succinate) was given to each of 9 normal subjects and to 20 patients with shock. Samples of blood were obtained immediately preceding the injection of cortisol sodium succinate and at $30,90,150,210$ and 270 minutes thereafter in the patients with shock. The blood specimens were treated as above. The sodium succinate ester of cortisol was employed because it is highly soluble and because it can be administered in a small volume of aqueous diluent in a few seconds. Hydrolysis of the ester is rapid and complete within 15 minutes after injection. The ester is not extracted from plasma by methylene chloride which is employed as the solvent in the determination of plasma cortisol (10). The rate of removal of cortisol from the plasma of pregnant women was determined after the rapid infusion of cortisol sodium succinate by Christy, Gordon, Longson, Wallace and Jailer (11). The disposal of this cortisol ester did not significantly differ from cortisol removal rates following infusions of cortisol free alcohol. Madsen, Done, Ely and Kelley (12) found no significant differences in the plasma half-time of cortisol whether administered as the free alcohol or the 21-hemisuccinate ester.

In patients with shock these procedures were carried out within a few hours after the recognition of peripheral circulatory failure.

\section{RESULTS}

\section{A. Relationship of the clinical status to the out- come}

The data recorded in Table I reveal that demonstrable bacteremia was associated with shock in 70 per cent of the cases. Gram-negative bacteria 
TABLE I

Clinical data on 22 patients with peripheral circulatory failure due to infection

\begin{tabular}{|c|c|c|c|c|c|c|c|c|}
\hline Age $^{\text {No. }}$ Sex & Diagnosis & Bacteriology & $\begin{array}{c}\text { Source of } \\
\text { bacteria }\end{array}$ & $\begin{array}{c}\text { Blood } \\
\text { pressure }\end{array}$ & $\begin{array}{l}\text { Duration } \\
\text { of hypo- } \\
\text { tension }\end{array}$ & $\begin{array}{l}\text { Temp. } \\
\text { in F. }\end{array}$ & $\begin{array}{c}\text { Skin } \\
\text { appearance }\end{array}$ & Outcome \\
\hline $28^{1} \mathrm{M}$ & Lobar pneumonia & $\begin{array}{l}\text { D. pneumo- } \\
\text { coccus }\end{array}$ & Sputum & $80 / 55$ & 24 hrs. & 105.0 & $\begin{array}{l}\text { Warm, } \\
\text { suffused }\end{array}$ & Recovered \\
\hline $70^{2} \mathrm{~F}$ & $\begin{array}{l}\text { Diabetes, urinary } \\
\text { tract infection }\end{array}$ & E. coli & $\begin{array}{l}\text { Blood } \\
\text { Urine }\end{array}$ & $60 / 30$ & 24 hrs. & 103.0 & $\begin{array}{l}\text { Warm, } \\
\text { suffused }\end{array}$ & Recovered \\
\hline $64^{3} \mathrm{M}$ & $\begin{array}{l}\text { Prostatic hypertrophy, } \\
\text { cystoscopy }\end{array}$ & E. coli & $\begin{array}{l}\text { Blood } \\
\text { Urine }\end{array}$ & $84 / 50$ & $16 \mathrm{hrs}$. & 104.4 & $\begin{array}{l}\text { Warm, } \\
\text { suffused }\end{array}$ & Recovered \\
\hline $54^{4} \mathrm{~F}$ & $\begin{array}{l}\text { Postoperative } \\
\text { ovarian cystectomy }\end{array}$ & E. coli & Urine & $50 / 30$ & 24 hrs. & 105.0 & $\begin{array}{l}\text { Warm, } \\
\text { suffused }\end{array}$ & Recovered \\
\hline $60^{5} \mathrm{M}$ & $\begin{array}{l}\text { Urethral stricture, } \\
\text { cystoscopy }\end{array}$ & Proteus & $\begin{array}{l}\text { Blood } \\
\text { Urine }\end{array}$ & $72 / 50$ & $12 \mathrm{hrs}$. & 103.2 & $\begin{array}{l}\text { Warm, } \\
\text { sufiused }\end{array}$ & Recovered \\
\hline $38^{6} \mathrm{M}$ & $\begin{array}{l}\text { Pseudomembranous } \\
\text { enteritis }\end{array}$ & Staph. & $\begin{array}{l}\text { Feces } \\
\text { Blood }\end{array}$ & $64 / 36$ & 36 hrs. & 104.0 & Cold, moist & Recovered \\
\hline $52^{7} \mathrm{M}$ & Miliary tuberculosis & M. tuberculosis & Sputum & $74 / 44$ & $24 \mathrm{hrs}$. & 104.0 & $\begin{array}{l}\text { Warm, } \\
\text { suffused }\end{array}$ & Recovered \\
\hline $79^{8} \mathrm{M}$ & $\begin{array}{l}\text { TUR, metastases from } \\
\text { cancer of renal pelvis }\end{array}$ & E. coli & $\begin{array}{l}\text { Blood } \\
\text { Urine }\end{array}$ & $80 / 50$ & 24 hrs. & 102.2 & $\begin{array}{l}\text { Warm, } \\
\text { suffused }\end{array}$ & Recovered \\
\hline $58^{9} \mathrm{~F}$ & $\begin{array}{l}\text { Osteomyelitis, } \\
\text { pyelonephritis }\end{array}$ & Staph. & $\begin{array}{l}\text { Blood } \\
\text { Wound }\end{array}$ & $86 / 56$ & 2 wks. & 104.0 & Cold, moist & Died \\
\hline $72^{10} \mathrm{~F}$ & $\begin{array}{l}\text { Chronic lymphatic } \\
\text { leukemia, peritonitis, } \\
\text { cirrhosis }\end{array}$ & Staph. & $\begin{array}{l}\text { Blood } \\
\text { Peri- } \\
\text { toneal } \\
\text { fluid }\end{array}$ & $50 / 0$ & $48 \mathrm{hrs}$. & 101.0 & Cold, moist & Died \\
\hline $60^{11} \mathrm{~F}$ & $\begin{array}{l}\text { Peritoneal abscess, } \\
\text { metastatic adeno- } \\
\text { carcinoma of colon }\end{array}$ & E. coli & Blood & $50 / 30$ & 48 hrs. & 102.0 & Cold, moist & Died \\
\hline $84^{12} \mathrm{M}$ & $\begin{array}{l}\text { Massive pneumonia, } \\
\text { renal abscess }\end{array}$ & Staph. & $\begin{array}{l}\text { Blood } \\
\text { Sputum }\end{array}$ & $75 / 50$ & $6 \mathrm{hrs}$. & 102.4 & Cold, moist & Died \\
\hline $73^{13} \mathrm{M}$ & $\begin{array}{l}\text { Cancer of prostate, } \\
\text { pneumonia }\end{array}$ & Staph. & $\begin{array}{l}\text { Sputum } \\
\text { Urine }\end{array}$ & $40 / 0$ & $18 \mathrm{hrs}$. & 104.0 & Cold, moist & Died \\
\hline $48^{14} \mathrm{~F}$ & $\begin{array}{l}\text { Perforated ulcer } \\
\text { with peritonitis }\end{array}$ & $\begin{array}{l}\text { Proteus } \\
\text { E. coli }\end{array}$ & $\begin{array}{l}\text { Peri- } \\
\text { toneal } \\
\text { fluid }\end{array}$ & & $8 \mathrm{hrs}$. & 97.0 & $\begin{array}{l}\text { Cold, } \\
\text { cyanotic }\end{array}$ & Died \\
\hline $85^{15} \mathrm{~F}$ & $\begin{array}{l}\text { Postoperative bowel } \\
\text { obstruction, staph. } \\
\text { septicemia with } \\
\text { metastatic abscesses }\end{array}$ & Staph. & $\begin{array}{l}\text { Blood } \\
\text { Urine }\end{array}$ & $70 / 40$ & 10 hrs. & 100.0 & $\begin{array}{l}\text { Cold, } \\
\text { cyanotic }\end{array}$ & Died \\
\hline $62^{16} \mathrm{M}$ & $\begin{array}{l}\text { Pyelonephritis, } \\
\text { cholangitis, } \\
\text { purpura, hepatic } \\
\text { abscesses }\end{array}$ & $\begin{array}{l}\text { Pseudomonas } \\
\text { E. coli }\end{array}$ & Blood & $60 / 40$ & 6 days & 104.0 & Cold, moist & Died \\
\hline $53^{17} \mathrm{M}$ & $\begin{array}{l}\text { Suppurative } \\
\text { peritonitis, } \\
\text { postoperative } \\
\text { gastrectomy }\end{array}$ & Pseudomonas & $\begin{array}{l}\text { Blood } \\
\text { Peri- } \\
\text { toneal } \\
\text { fluid }\end{array}$ & $55 / 0$ & 6 days & 103.0 & Cold, moist & Died \\
\hline $62^{18} \mathrm{~F}$ & Pulmonary emboli & $\begin{array}{l}\text { E. coli } \\
\text { Strep. viridans }\end{array}$ & $\begin{array}{l}\text { Urine } \\
\text { Blood }\end{array}$ & $80 / 50$ & 10 days & 101.0 & Warm, dry & Died \\
\hline $67^{19} \mathrm{M}$ & $\begin{array}{l}\text { Total gastrectomy for } \\
\text { cancer of stomach, } \\
\text { post-gastrectomy }\end{array}$ & $\begin{array}{l}\text { Proteus } \\
\text { Staph. } \\
\text { Pseudomonas }\end{array}$ & $\begin{array}{l}\text { Sub- } \\
\text { phrenic } \\
\text { abscess } \\
\text { Empyema }\end{array}$ & $80 / 0$ & 10 days & 103.0 & $\begin{array}{l}\text { Cold, } \\
\text { cyanotic }\end{array}$ & Died \\
\hline
\end{tabular}


TABLE I-Continued

\begin{tabular}{cllllllll}
\hline $\begin{array}{c}\text { No. } \\
\text { Age Sex }\end{array}$ & \multicolumn{1}{c}{ Diagnosis } & Bacteriology & $\begin{array}{c}\text { Source of } \\
\text { bacteria }\end{array}$ & $\begin{array}{c}\text { Blood } \\
\text { pressure }\end{array}$ & $\begin{array}{c}\text { Duration } \\
\text { of hypo- } \\
\text { tension }\end{array}$ & $\begin{array}{c}\text { Temp. } \\
\text { in F. }\end{array}$ & $\begin{array}{c}\text { Skin } \\
\text { appearance }\end{array}$ & Outcome \\
\hline $7^{20} \mathrm{M}$ & $\begin{array}{l}\text { Postoperative } \\
\text { cholecystectomy, } \\
\text { diabetes mellitus }\end{array}$ & E. coli & Blood & $66 / 30$ & 24 hrs. & 102.0 & Cold, moist & Died \\
$8^{21} \mathrm{M}$ & Urethral stricture & E. coli & $\begin{array}{l}\text { Urine } \\
\text { Blood }\end{array}$ & $78 / 50$ & $24 \mathrm{hrs.}$ & 101.0 & $\begin{array}{l}\text { Warm, } \\
\text { suffused }\end{array}$ & Recovered \\
$75^{22} \mathrm{M}$ & $\begin{array}{l}\text { Postoperative } \\
\text { cancer of stomach }\end{array}$ & $\begin{array}{l}\text { Pseudomonas } \\
\text { aeruginosa }\end{array}$ & $\begin{array}{l}\text { Urine } \\
\text { Sputum }\end{array}$ & $80 / 54$ & $24 \mathrm{hrs}$. & 103.0 & $\begin{array}{l}\text { Warm, } \\
\text { suffused }\end{array}$ & Recovered \\
\hline
\end{tabular}

were most frequently isolated. The severity of the underlying infectious process is emphasized by the fact that staphylococci were isolated from the blood in 50 per cent of those who died. Nine autopsies were performed in the series and no adrenal pathological change could be demonstrated, except in one patient, who had a hematoma of a single adrenal. A characteristic difference in the appearance of those who died from those who recovered was recorded frequently enough to note. The patients who succumbed displayed more often an ashen gray, cold, moist skin with mottling and cyanosis such as is encountered in severe hemorrhagic shock. The survivors had suffused, warm skin and a full pulse in the presence of hypotension. The dichotomy in the clinical picture of shock has been reported by Waisbren (13) and by Hall and Gold (14). The two groups differed significantly in the period of time they remained hypotensive. Whereas the patients who recovered were hypo- tensive for an average of 23 hours, the patients who succumbed were hypotensive for an average of six to seven days. Pressor substances were used to maintain blood pressure during the hypotensive period and all patients were considered to be hypotensive until they no longer required pressor substances for the maintenance of blood pressure.

\section{B. Concentration of cortisol in the plasma}

The results of this study are given in Table II. In the healthy subjects the concentrations of plasma cortisol averaged $13 \mu \mathrm{g}$. per $100 \mathrm{ml}$., with a range of from 7 to $22 \mu \mathrm{g}$. per $100 \mathrm{ml}$. In this control group, all samples were obtained at 8:00 a.m. The mean plasma cortisol concentrations of patients with shock due to infection was $63 \mu \mathrm{g}$. per $100 \mathrm{ml}$., ranging from 30 to $160 \mu \mathrm{g}$. per 100 $\mathrm{ml}$. The mean plasma cortisol concentration for the patients in shock was initially higher than

TABLE II

Concentration of cortisol in the plasma

\begin{tabular}{|c|c|c|c|c|c|c|c|c|c|c|c|}
\hline & & & & \multicolumn{8}{|c|}{ Patients with shock due to infection } \\
\hline \multicolumn{4}{|c|}{ Normal subjects } & \multicolumn{4}{|c|}{ Survivors } & \multicolumn{4}{|c|}{ Fatalities } \\
\hline No. & Age & Sex & $\mu \mathrm{g} . / 100 \mathrm{ml}$. & No. & Age & Sex & Mg. $/ 100 \mathrm{ml}$. & No. & Age & Sex & $\mu \mathrm{g} . / 100 \mathrm{ml}$. \\
\hline $\begin{array}{l}1 \\
2 \\
3 \\
4 \\
5 \\
6 \\
7 \\
8 \\
9\end{array}$ & $\begin{array}{l}24 \\
23 \\
23 \\
19 \\
37 \\
22 \\
23 \\
31 \\
42\end{array}$ & $\begin{array}{l}\mathbf{M} \\
\mathbf{M} \\
\mathbf{M} \\
\mathbf{F} \\
\mathbf{F} \\
\mathbf{M} \\
\mathbf{M} \\
\mathbf{M} \\
\mathbf{M}\end{array}$ & $\begin{array}{r}11 \\
12 \\
9 \\
22 \\
10 \\
16 \\
7 \\
17 \\
11\end{array}$ & $\begin{array}{l}1 \\
2 \\
3 \\
4 \\
5 \\
6 \\
7 \\
8\end{array}$ & $\begin{array}{l}28 \\
70 \\
64 \\
54 \\
60 \\
38 \\
52 \\
79\end{array}$ & $\begin{array}{l}\mathbf{M} \\
\mathbf{F} \\
\mathbf{M} \\
\mathbf{F} \\
\mathbf{M} \\
\mathbf{M} \\
\mathbf{M} \\
\mathbf{M}\end{array}$ & $\begin{array}{l}47 \\
40 \\
49 \\
53 \\
41 \\
43 \\
40 \\
78\end{array}$ & $\begin{array}{r}9 \\
10 \\
11 \\
12 \\
13 \\
14 \\
15 \\
16 \\
17 \\
18 \\
19 \\
20\end{array}$ & $\begin{array}{l}58 \\
72 \\
60 \\
84 \\
73 \\
48 \\
85 \\
62 \\
53 \\
62 \\
67 \\
72\end{array}$ & $\begin{array}{l}\mathbf{F} \\
\mathbf{F} \\
\mathbf{F} \\
\mathbf{M} \\
\mathbf{M} \\
\mathbf{F} \\
\mathbf{F} \\
\mathbf{M} \\
\mathbf{M} \\
\mathbf{F} \\
\mathbf{M} \\
\mathbf{M}\end{array}$ & $\begin{array}{r}30 \\
82 \\
69 \\
120 \\
61 \\
160 \\
72 \\
45 \\
68 \\
36 \\
54 \\
74\end{array}$ \\
\hline \multicolumn{4}{|c|}{$\begin{array}{l}\text { Mean }=13 \pm 4^{*} \\
\text { Range }=7-22\end{array}$} & \multicolumn{4}{|c|}{$\begin{array}{l}\text { Mean }=50 \pm 12 \\
\text { Range }=40-78\end{array}$} & \multicolumn{4}{|c|}{$\begin{array}{l}\text { Mean }=73 \pm 34 \\
\text { Range }=30-160\end{array}$} \\
\hline
\end{tabular}

* Standard deviation. 
the mean plasma cortisol concentration in normals after a four hour infusion of corticotropin. In only one patient with shock was the plasma cortisol level within the normal range as obtained in this laboratory. The highest concentrations were found in the moribund patients.

\section{Effect of an intravenous infusion of cortico- tropin on plasma cortisol concentrations}

The results for normal subjects and for patients are summarized in Tables III and IV. Four hour intravenous corticotropin tests were performed in eight normal individuals. The mean control value for cortisol was $15 \mu \mathrm{g}$. per 100 $\mathrm{ml}$. of plasma, with a range of 5 to $24 \mu \mathrm{g}$. per cent. Following the infusion of corticotropin, the concentrations rose to a range of 32 to $63 \mu \mathrm{g}$. per cent with a mean of $46 \mu \mathrm{g}$. per cent. Rarely have values exceeded $65 \mu \mathrm{g}$. per cent in normal subjects after corticotropin. Four hour corticotropin tests were carried out in six patients with shock. The initial plasma cortisol levels averaged $53 \mu \mathrm{g}$. per $100 \mathrm{ml}$. and ranged from 36 to 76 $\mu \mathrm{g}$. per $100 \mathrm{ml}$. After a four hour infusion of corticotropin the cortisol levels rose to an average level of $100 \mu \mathrm{g}$. per $100 \mathrm{ml}$. of plasma, with a range of 81 to $119 \mu \mathrm{g}$. per $100 \mathrm{ml}$. Three of the patients given corticotropin, all of whom died (Nos. 18, 19 and 20), had average postcorticotropin infusion levels of $112 \mu \mathrm{g}$. per $100 \mathrm{ml}$. of plasma, whereas the mean value in three patients who recovered was $88 \mu \mathrm{g}$. per $100 \mathrm{ml}$. Sand-

TABLE III

Effect of corticotropin (25 U.S.P. units intravenously over a four hour period) on plasma cortisol concentrations in normal subjects

\begin{tabular}{|c|c|c|c|c|c|}
\hline \multirow[b]{2}{*}{$\begin{array}{l}\text { Subject } \\
\text { no. }\end{array}$} & \multirow[b]{2}{*}{ Age } & \multirow[b]{2}{*}{ Sex } & & \multicolumn{2}{|c|}{ Plasma cortisol ( $\mu \mathrm{g} . / 100 \mathrm{ml}$. ) } \\
\hline & & & & $\begin{array}{l}\text { Before } \\
\text { cortico- } \\
\text { tropin }\end{array}$ & $\begin{array}{c}\text { After } \\
\text { cortico- } \\
\text { tropin }\end{array}$ \\
\hline \multirow[t]{2}{*}{$\begin{array}{l}1 \\
2 \\
3 \\
4 \\
5 \\
6 \\
7 \\
8\end{array}$} & $\begin{array}{l}54 \\
37 \\
45 \\
72 \\
31 \\
52 \\
21 \\
36\end{array}$ & $\begin{array}{l}\mathbf{M} \\
\mathbf{M} \\
\mathbf{M} \\
\mathbf{M} \\
\mathbf{F} \\
\mathbf{F} \\
\mathbf{F} \\
\mathbf{F}\end{array}$ & & $\begin{array}{r}16 \\
5 \\
19 \\
15 \\
10 \\
24 \\
14 \\
21\end{array}$ & $\begin{array}{l}52 \\
32 \\
40 \\
63 \\
33 \\
44 \\
51 \\
52\end{array}$ \\
\hline & & & $\begin{array}{l}\text { Mean } \\
\text { Range }\end{array}$ & $\begin{array}{l}=15 \pm 6^{*} \\
e=5-24\end{array}$ & $\begin{array}{l}\text { Mean }=46 \pm 10 \\
\text { Range }=32-63\end{array}$ \\
\hline
\end{tabular}

\footnotetext{
* Standard deviation.
}

TABLE IV

Effect of corticotropin (25 U.S.P. units intravenously over a four hour period) on plasma cortisol concentrations in patients with shock due to infection

\begin{tabular}{|c|c|c|c|c|c|}
\hline \multirow[b]{2}{*}{$\begin{array}{l}\text { Patient } \\
\text { no. }\end{array}$} & \multirow{2}{*}{\multicolumn{2}{|c|}{ Age Sex }} & \multirow[b]{2}{*}{ Outcome } & \multicolumn{2}{|c|}{ Plasma cortisol ( $\mu \mathrm{g} . / 100 \mathrm{ml})}$. \\
\hline & & & & $\begin{array}{c}\text { Before } \\
\text { cortico- } \\
\text { tropin }\end{array}$ & $\begin{array}{l}\text { After } \\
\text { cortico- } \\
\text { tropin }\end{array}$ \\
\hline \multirow[t]{2}{*}{$\begin{array}{r}18 \\
20 \\
19 \\
3 \\
21 \\
22\end{array}$} & $\begin{array}{l}62 \\
72 \\
67 \\
64 \\
86 \\
75\end{array}$ & $\begin{array}{l}\mathbf{F} \\
\mathbf{M} \\
\mathbf{M} \\
\mathbf{M} \\
\mathbf{M} \\
\mathbf{M}\end{array}$ & $\begin{array}{c}\text { Died } \\
\text { Died } \\
\text { Died } \\
\text { Recovered } \\
\text { Recovered } \\
\text { Recovered }\end{array}$ & $\begin{array}{l}36 \\
76 \\
51 \\
57 \\
45 \\
57\end{array}$ & $\begin{array}{r}119 \\
104 \\
114 \\
81 \\
96 \\
86\end{array}$ \\
\hline & & & & $\begin{aligned} \text { Mean } & =53 \\
\text { Range } & =36- \\
& 76\end{aligned}$ & $\begin{array}{l}\text { Mean }=100 \\
\text { Range }=\begin{array}{r}81 \\
119\end{array}\end{array}$ \\
\hline
\end{tabular}

berg, Eik-Nes, Migeon and Samuels (15) have reported similar values in agonal patients. In their study the injection of cortisol-4-C ${ }^{14}$ into dying patients resulted in a reduced urinary excretion of radioactive metabolites when compared with the normal. They concluded that the high levels of plasma cortisol that they obtained were due to impaired metabolism in the presence of normally functioning adrenals. Urinary 17-hydroxycorticosteroid determinations were not made in the patients reported in this study because nearly all of the patients were oliguric and some rapidly developed azotemia. Under usual circumstances the excretion of urinary 17-hydroxycorticosteroids is a valuable index of cortisol production. But in shock, where there exists a reduction in urinary output coupled with retention of conjugated cortisol metabolites in the plasma, the results would be unreliable (16).

\section{The rate of disappearance of infused cortisol sodium succinate from the plasma}

Levels of plasma cortisol following the rapid infusion of $100 \mathrm{mg}$. of cortisol sodium succinate are shown in Figure 1. It is to be recalled that the mean initial plasma concentrations of cortisol in the patients who recovered and in those who died were significantly elevated compared to the values found in the normal subjects. However, in the patients who died, the initial levels were higher than those in the patients who survived. Levels of cortisol in the plasma after the infusion of cortisol sodium succinate are plotted on semilogarithmic paper at various time intervals. The 
initial preinfusion or endogenous values are not subtracted from the subsequent postinfusion levels. It should be noted that in the patients who survived most of the postinfusion plasma cortisol concentrations were less than the initial concentration of endogenous cortisol. Scheuer and Bondy (17) demonstrated in healthy subjects that plasma cortisol concentrations were lower than endogenous preinjection concentrations at five to seven hours after the injection of $100 \mathrm{mg}$. of cortisol-free alcohol. It cannot be assumed that the basal plasma levels of cortisol remain constant after an infusion of cortisol in the "stressed" subject in the light of considerable experimental evidence. Sydnor (18) has shown that the intravenous administration of cortisol to bilaterally adrenalectomized "stressed" rats effectively inhibits corticotropin secretion. Brodish and Long (19) in similar experiments found that complete inhibition of corticotropin release is accomplished within $\mathbf{5}$ to 20 minutes following the infusion of cortisol. Richards and Pruitt (20), using permanent adrenal vein cannulas in dogs, suppressed maximal adrenal secretory acivity after the induction of respiratory acidosis and operative trauma by infusions of cortisol. Thus, it would seem unjustified to subtract initial plasma cortisol values from postinfusion values in patients with shock.

In Table $\mathrm{V}$, the individual plasma biological

TABLE $v$

Biological half-time of plasma cortisol after the intravenous injection of $100 \mathrm{mg}$. of cortisol as the 21-hemisuccinate

\begin{tabular}{|c|c|c|c|c|c|}
\hline \multirow{2}{*}{\multicolumn{2}{|c|}{ Healthy adults }} & \multicolumn{4}{|c|}{ Patients with shock due to infection } \\
\hline & & \multicolumn{2}{|c|}{ Survivors } & \multicolumn{2}{|c|}{ Fatalities } \\
\hline $\begin{array}{c}\text { Subject } \\
\text { no. }\end{array}$ & $\begin{array}{c}\mathrm{T} \\
(\mathrm{min} .)\end{array}$ & $\begin{array}{l}\text { Patient } \\
\text { no. }\end{array}$ & $\underset{(\min .)}{\mathrm{T}}$ & $\begin{array}{l}\text { Patient } \\
\text { no. }\end{array}$ & $\begin{array}{c}\mathrm{T} \frac{1}{3} \\
\text { (min.) }\end{array}$ \\
\hline $\begin{array}{l}1 \\
2 \\
3 \\
4 \\
5 \\
6 \\
7 \\
8\end{array}$ & $\begin{array}{r}110.0 \\
102.1 \\
78.9 \\
65.7 \\
112.5 \\
131.2 \\
70.0 \\
142.8\end{array}$ & $\begin{array}{l}1 \\
2 \\
3 \\
4 \\
5 \\
6 \\
7 \\
8\end{array}$ & $\begin{array}{r}106.2 \\
79.5 \\
85.9 \\
87.1 \\
105.8 \\
80.6 \\
95.4 \\
120.0\end{array}$ & $\begin{array}{r}9 \\
10 \\
11 \\
12 \\
13 \\
14 \\
15 \\
16 \\
17 \\
18 \\
19 \\
20\end{array}$ & $\begin{array}{r}169.1 \\
332.3 \\
566.1 \\
661.5 \\
300.0 \\
592.1 \\
360.8 \\
578.8 \\
1,020.3 \\
444.3 \\
420.0 \\
173.0\end{array}$ \\
\hline $\begin{array}{l}\text { Mean } \\
\text { Range }\end{array}$ & $\begin{array}{l}=101.6 \\
=\begin{array}{c}65.7- \\
142.8\end{array}\end{array}$ & $\begin{array}{l}\text { Mean } \\
\text { Range }\end{array}$ & 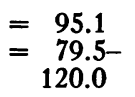 & $\begin{array}{l}\text { Mean } \\
\text { Range }\end{array}$ & $\begin{aligned}= & 468.2 \\
= & 169.1- \\
& 1,020.3\end{aligned}$ \\
\hline
\end{tabular}

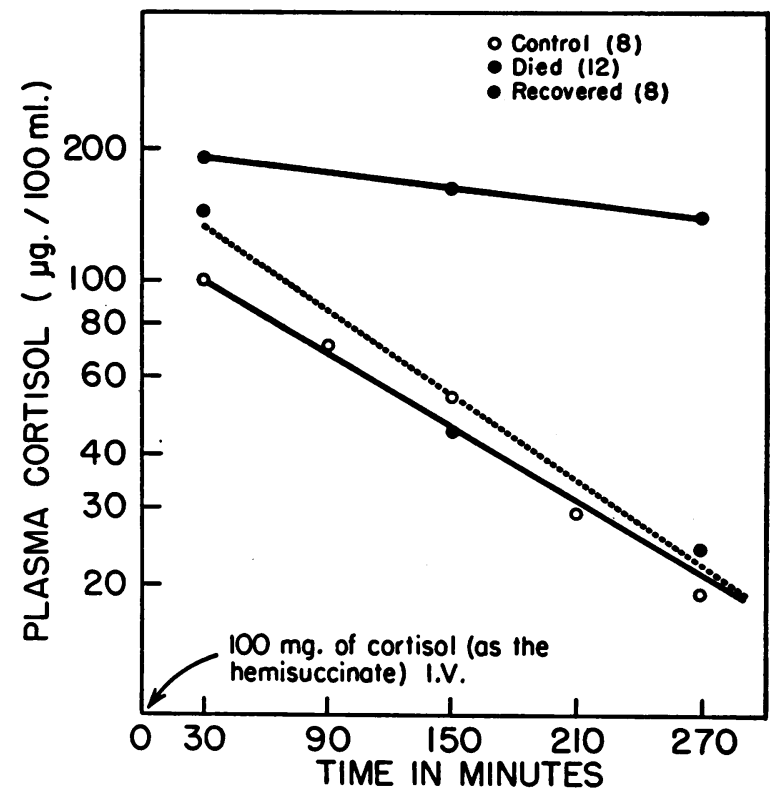

Fig. 1. Rate of Disappearance of Cortisol (INjected as the 21-Hemisuccinate) from Plasma of Patients with Shock Due to Infection

half-times for cortisol were compared in healthy subjects, in patients who survived and in patients who died from shock due to severe infection. The mean biological half-time of cortisol in the normal subjects was found to be 101.6 minutes. In patients who recovered, this value was 95.1 minutes and in those who died, 468.2 minutes. The biological half-time of cortisol in the plasma is determined to a large extent by the functional integrity of the liver (16). Liver function tests were performed in six of the moribund patients. These were abnormal in all six patients tested. Liver function was assessed in four of the patients who survived and was found to be normal in all four patients. The half-time values of plasma cortisol in the healthy subjects and in the patients who survived are not significantly different.

\section{DISCUSSION}

The most significant feature in this study is that patients with shock due to an infection did not exhibit evidence of adrenal insufficiency. High concentrations of cortisol were present in the plasma in all patients studied. Furthermore, even in agonal patients there was a continued response of the adrenals to stimulation with corticotropin. 
The high levels of cortisol in the plasma of the patients who recovered would appear to be solely due to an acceleration of the rate of production of endogenous cortisol because the administered cortisol disappeared from the plasma at a normal rate. On the other hand, the greater concentration of cortisol in the plasma of moribund patients may be accounted for, in part, by factors retarding the removal of cortisol from the blood and by increased cortisol production. The relative contribution of adrenal secretory activity to the high blood levels of cortisol could not be determined in the presence of impeded removal of injected cortisol from the plasma in the moribund patients. However, documented clinical and experimental evidence indicates that adrenal secretion of cortisol may be supranormal under similar conditions, in that the blood cortisol and urinary 17-hydroxycorticosteroid excretion were markedly elevated in patients dying of severe burns (21). Dogs subjected to hemorrhagic shock demonstrated a maximal secretion of cortisol (22). The shock induced in dogs by lethal injections of bacterial endotoxin is associated with high blood levels of cortisol and maximal secretion of cortisol in the adrenal venous effluent (23).

Factors influencing the slope of the plasma cortisol removal curves have been reviewed by Samuels, Brown, Eik-Nes, Tyler and Dominguez (16). If the curves plotted in Figure 1 are extrapolated to zero time it will be seen that the values obtained for the survivors and fatalities are not significantly different. Samuels and coworkers (16) refer to this value as the "apparent distribution volume" of cortisol. Thus, it appears unlikely that changes in the volume distribution of cortisol account for the difference observed. Impairment of hepatocellular function, hepatic blood flow, renal function and thyroid function all operate to reduce the rate of metabolic disposal of cortisol. All patients studied who were moribund were either markedly oliguric or anuric. The patients who survived demonstrated less significant abnormalities of renal function, i.e., mild azotemia and transient oliguria.

Among the patients who died of bacterial shock, significant abnormalities of liver function were demonstrated. In none of the survivors studied was hepatic function significantly disturbed. In human patients major surgical pro- cedures (24), agonal states (15), certain acute infectious diseases in childhood (25), myxedema (26) and liver disease (27) have been associated with reduced plasma cortisol removal rates. Tourniquet shock (28) retards the turnover of cortisol-4-C ${ }^{14}$ in the rat. In the dog lethal doses of endotoxin induce shock and slow the removal of injected cortisol from the plasma (23).

Eik-Nes and Samuels (29) have roughly correlated the severity of "stress" with the degree of impairment of cortisol removal from the plasma of the dog-the more severe or lethal the "stress," the greater the reduction of the rate of removal of cortisol from the plasma. Our own studies confirm this view (30). It should be pointed out that small doses of bacterial polysaccharide ( 0.1 to $2.0 \mu \mathrm{g}$.) injected into the dog accelerate the removal of exogenous cortisol from the plasma, whereas larger doses have the opposite effect. These observations supplement the results of McDonald, Weise and Peterson (31) who injected a bacterial pyrogen (Piromen $\left.{ }^{(}\right)$into humans and noted a rise in plasma cortisol and an acceleration of the removal of exogenous cortisol from the plasma.

Although several factors probably influence the removal rate of exogenous cortisol from the plasma, it is conceivable that one of the most important independent variables in this study was the size of the bacterial inoculum and the amount of endotoxin made available.

Peterson, Pierce, Wyngaarden, Bunim and Brodie (32) have been unable to correlate the rate of disposal of cortisol or its analogs with its biological activity. Neither does cortisol exert its biological effects as a by-product of its catabolism. Any speculation as to rate of "utilization" of cortisol is not relevant. The term "relative adrenal insufficiency" in vascular collapse due to infection is misleading because the concentration of biologically active cortisol in the plasma is supraphysiologic. Daughaday (33) has demonstrated two protein binding systems for cortisol in the plasma. The first, a globulin, is saturated at plasma levels of between 15 and $30 \mu \mathrm{g}$. per $100 \mathrm{ml}$. The second, albumin, binds cortisol more loosely and can accomodate high plasma concentrations of cortisol. This system is easily reversible and readily allows dissociation of cortisol so that it may traverse the capillary 
membranes and become directly available to the tissues. Thus, it is likely that when the globulin system is exceeded the excess of plasma cortisol is freely diffusible. In the present study it would appear that under normal conditions adequate amounts of diffusible cortisol were available to the tissues in all of the patients studied. But under the unphysiologic conditions of shock these hormonal concentrations are insufficient. Observations on patients in shock and investigations in animals with endotoxin shock make it apparent that the necessary amount of exogenous cortisol or its synthetic analogs far exceeds that which can be produced by maximal endogenous secretory activity (5).

The importance of the relationship between the plasma concentration of readily diffusible cortisol and the degree of tissue injury has been demonstrated experimentally. These studies will be reported in detail elsewhere (34), but the essential data can be cited here. After dogs had been injected intravenously with endotoxin prepared from $E$. coli, there was a prompt rise in the plasma concentration of cortisol, and a rise in the level of serum glutamic oxaloacetic transaminase. It is generally assumed that elevations in serum transaminase are associated with cellular injury. It was apparent that maximal endogenous secretion of cortisol did not prevent the rise in transaminase levels. However, when large doses of cortisol were administered to the dogs along with the endotoxin there was only a small rise in the levels of transaminase. These observations suggest that the level of cortisol concentrations found within the physiological range are inadequate for protection against tissue injury. These observations support the concept that if cortisol is to be used as a therapeutic agent in fulminant sepsis with vascular collapse, its action and therefore its dose should be pharmacologic. In this context it does not represent "replacement" therapy.

\section{SUMMARY}

1. Adrenal function was studied in 17 healthy adults and in 22 adult patients having shock due to infection. Three quantitative studies were employed. First, the basal plasma cortisol level was determined. Second, the response of the adrenal to stimulation with corticotropin was measured in terms of change in plasma cortisol concentration. Third, the biological half-time of exogenous cortisol injected as the succinate ester in plasma was evaluated.

2. All of the patients with shock had considerably higher basal concentrations of cortisol in the plasma than did the healthy subjects. In six patients with shock who were studied there was a response to corticotropin similar to that obtained in the healthy adults. The biological half-time of exogenous cortisol was not different from healthy subjects in those patients with shock who survived, but in those patients having fatal shock the biological half-time was considerably more prolonged than that observed in healthy subjects. The significance of these differences is discussed.

3. Accelerated adrenal secretory activity was demonstrated in those patients who survived. In moribund patients unequivocal proof for increased adrenal secretory activity could not be obtained.

\section{ACKNOWLEDGMENT}

We deeply appreciate the technical assistance of Mrs. Harriet A. Aaker.

\section{REFERENCES}

1. Waterhouse, R. Case of suprarenal apoplexy. Lancet 1911, 1, 577.

2. Friderichsen, C. Nebennierenapoplexie bei kleinen Kindern. Jb. Kinderheilk. 1918, 87, 109.

3. Keefer, C. S. Infections in Medical Uses of Cortisone Including Hydrocortisone and Corticotropin, F. D. W. Lukens, Ed. New York, Blakiston, 1954, p. 401.

4. Kass, E. H., and Finland, M. Adrenocortical hormones and the management of infection. Ann. Rev. Med. 1957, 8, 1.

5. Spink, W. W. ACTH and adrenocorticosteroids as therapeutic adjuncts in infectious diseases. New Engl. J. Med. 1957, 257, 979 and 1031.

6. Melby, J. C., Egdahl, R. H., and Spink, W. W. Effect of brucella endotoxin on adrenocortical function in the dog. Fed. Proc. 1957, 16, 425.

7. Bush, I. E., and Sandberg, A. A. Adrenocortical hormones in human plasma. J. biol. Chem. 1953, 205, 783.

8. Silber, R. H., and Porter, C. C. The determination of 17,21-dihydroxy-20-ketosteroids in urine and plasma. J. biol. Chem. 1954, 210, 923.

9. Peterson, R. E., Karrer, A., and Guerra, S. L. Evaluation of Silber-Porter procedure for determination of plasma hydrocortisone. Analyt. Chem. 1957, 29, 144. 
10. Silber, R. H. Personal communication.

11. Christy, N. P., Gordon, W. E. L., Longson, D., Wallace, E. Z., and Jailer, J. W. Some observations upon adrenal cortical function during pregnancy. Program of the Fortieth Annual Meeting of The Endocrine Society, June 19, 1958, San Francisco, Calif.

12. Madsen, J., Done, A. K., Ely, R. S., and Kelley, V. C. Evaluation of water soluble hemisuccinate esters of hydrocortisone and prednisolone: Plasma 17hydroxycorticosteroid concentrations following intravenous administration. A. M. A. J. Dis. Child. In press.

13. Waisbren, B. A. Bacteremia due to gram-negative bacilli other than Salmonella; clinical and therapeutic study. A. M. A. Arch. intern. Med. 1951, 88, 467.

14. Hall, W. H., and Gold, D. Shock associated with bacteremia : Review of thirty-five cases. A. M. A. Arch. intern. Med. 1955, 96, 403.

15. Sandberg, A. A., Eik-Nes, K., Migeon, C. J., and Samuels, L. T. Metabolism of adrenal steroids in dying patients. J. clin. Endocr. 1956, 16, 1001.

16. Samuels, L. T., Brown, H., Eik-Nes, K., Tyler, F. H., and Dominguez, O. V. Extra-adrenal factors affecting the levels of 17-hydroxycorticosteroids in plasma in Ciba Foundation Colloquia in Endocrinology. Vol. XI. Hormones in Blood, G. E. W. Wolstenholme and E. C. P. Millar, Eds. Boston, Little, Brown and Co., 1957, pp. 208-230.

17. Scheuer, J., and Bondy, P. K. The effect of intravenous cortisol injections on the plasma cortisol concentration in man. J. clin. Invest. 1957, 36, 67.

18. Sydnor, K. L. Blood ACTH in the stressed adrenalectomized rat after intravenous injection of hydrocortisone. Endocrinology 1955, 56, 204.

19. Brodish, A., and Long, C. N. H. Mechanism of inhibition of ACTH release by hydrocortisone. Program of the Fortieth Annual Meeting of The Endocrine Society, June 20, 1958, San Francisco, Calif.

20. Richards, J. B., and Pruitt, R. L. Hydrocortisone suppression of stress induced adrenal 17-hydroxycorticosteroid secretion in dogs. Research Report. Project NM 007081.22.13, Naval Medical Research Institute, 1956, vol. 14, p. 601.

21. Hume, D. M., Nelson, D. H., and Miller, D. W. Blood and urinary 17-hydroxycorticosteroids in patients with severe burns. Ann. Surg. 1956, 143, 316.
22. Hume, D. M., and Nelson, D. H. Adrenal cortical function in surgical shock in Surgical Forum, The American College of Surgeons (1954), Vol. V. Philadelphia, W. B. Saunders and Co., 1955, pp. 568-575.

23. Melby, J. C., DeWall, R. A., Storey, J. L., and Egdahl, R. H. The production and catabolism of cortisol in experimental endotoxin shock (abstract). J. clin. Invest. 1957, 36, 914.

24. Sandberg, A. A., Eik-Nes, K., Samuels, L. T., and Tyler, F. H. The effects of surgery on the blood levels and metabolism of 17-hydroxycorticosteroids in man. J. clin. Invest. 1954, 33, 1509.

25. Done, A. K., and Kelley, V. C. The half-life of exogenous adrenocorticosteroids in health and disease. J. clin. Endocr. 1956, 16, 921.

26. Peterson, R. E., Wyngaarden, J. B., Guerra, S. L., Brodie, B. B., and Bunim, J. J. The physiological disposition and metabolic fate of hydrocortisone in man. J. clin. Invest. 1955, 34, 1779.

27. Brown, H., Willardson, D. G., Samuels, L. T., and Tyler, F. H. 17-Hydroxycorticosteroid metabolism in liver disease. J. clin. Invest. 1954, 33, 1524.

28. Firschein, H. E., DeVenuto, F., Fitch, W. M., Pearce, E. M., and Westphal, U. Distribution of injected cortisol-4-C $\mathrm{C}^{\mathbf{1 4}}$ in normal and shocked rats. Endocrinology 1957, 60, 347.

29. Eik-Nes, K. B., and Samuels, L. T. Metabolism of cortisol in normal and "stressed" dogs. Endocrinology 1958, 63, 82.

30. Melby, J. C., and Spink, W. W. Unpublished observations.

31. McDonald, R. K., Weise, V. K., and Peterson, R. E. Effect of aspirin and reserpine on adrenocortical response to Piromen in man. Proc. Soc. exp. Biol. (N. Y.) 1956, 93, 343.

32. Peterson, R. E., Pierce, C. E., Wyngaarden, J. B., Bunim, J. J., and Brodie, B. The physiological disposition and metabolic fate of cortisone in man. J. clin. Invest. 1957, 36, 1301.

33. Daughaday, W. H. Binding of corticosteroids by plasma proteins. III. The binding of corticosteroid and related hormones by human plasma and plasma protein fractions as measured by equilibrium dialysis. J. clin. Invest. 1958, 37, 511.

34. Melby, J. C., Egdahl, R. H., and Spink, W. W. Cortisol suppression of endotoxin induced serum transaminase elevation. J. clin. Endocr. In press. 